\title{
Experimental Study on the Pavement Performance of Cement- Improved Silty Fine Sand
}

\author{
Chen Wei ${ }^{1{ }^{1 *}}$, Huang Zhijun ${ }^{1,2}$,Tang Yulong ${ }^{3}$,and Duan Dahong ${ }^{4}$ \\ ${ }^{1}$ Lan Zhou Jiaotong University,Lan Zhou,Gansu Province,China \\ ${ }^{2}$ Key Laborayory of road,bridge and underground engineering of Gansu Province,Lan Zhou,Gansu Province, China \\ ${ }^{3}$ China Railway First Survey and Design Institute, Lan Zhou,Gansu Province, China \\ ${ }^{4}$ Gansu Jiu E Railway Co.,Ltd,Jiu Quan,Gansu Province,China
}

\begin{abstract}
In view of the fact that there is in shortage of superior roadbed fillers in gobi and desert areas and based on the economical and environment-friendly concept, the cement-improved silty fine sand will be used as the roadbed filler of a railway construction project, which has the engineering characteristics of difficult compaction of local silty fine sands and loose structure, within the territory of Jiuquan, Gansu Province.The test indicated that the actual silty fine sands presented relatively concentrated particle sizes in this project, the particle composition was uniform and difficult to compact. The $7 \mathrm{~d}$ saturated unconfined compressive strength of the cement-improved silty fine sand filler was correlated with the cement content, curing age and compaction coefficient, and also showed a good linear fitting relation with the cement content. As the delay time of sample molding was lengthened, the $7 \mathrm{~d}$ saturated unconfined compressive strength of the samples was gradually reduced, and the strength retention rate had a favorable fitting relation with the delay time of sample molding. The compaction coefficient was detected using the sand-cone method in the field compaction test, and on this basis, the "ex post detection" method was proposed to detect the compaction coefficient of this special type of fillers.
\end{abstract}

\section{Introduction}

For a railway construction project within the territory of Jiuquan, Gansu Province, the area that the rail track passes through mainly presents the topographic forms of desert and gobi. Due to its special geological geologic conditions and lack of superior roadbed fillers, the distant transportation scheme will cause the high engineering cost, and moreover, it fails to meet the green and environmentfriendly requirements ${ }^{[1]}$. Through the comprehensive comparison and selection, the local cement-improved silty fine sands along the railway can be used as the roadbed fillers to lower the engineering cost and accelerate the project progress. In this study, a laboratory test of the silty fine sands collected on the field and cement-improved silty fine sands was firstly carried out, the value range and change laws of their physical and mechanical indexes were obtained, and on this basis, the feasibility of usage of cement-improved silty fine sands as the roadbed filler was verified through the field compaction test. In the meantime, the relationships of strength of cement-improved silty fine sand with the curing age, cement content, compaction coefficient and delay time of sample molding were summarized.

After a series of tests of silty fine sands on a highway in Dunhuang, Wang $\mathrm{H} \mathrm{L}^{[1]}$ analyzed the engineering properties and key construction technologies of silty fine sand filler in this area by combining the stability analysis of embankment slope. Zhang B W ${ }^{[2]}$ summarized the basic physical and mechanical properties of cement-improved silty fine sands through a laboratory test, and analyzed its durability. Tang Y L ${ }^{[3]}$ analyzed and summarized the influencing factors of cement-improved silty fine sands. Zhang $\mathrm{Y}^{[4]}$ experimentally explored the compaction characteristics of aeolian sand. Yan D F ${ }^{[5]}$ studied the influence of cement-improved soil on its delay time. In an engineering practice, the laboratory test and field test were combined in this paper to systematically analyze the pavement performance of cement-improved silty fine sand.

\section{Physical Properties of Soil Samples}

\subsection{Analysis test of silty fine sand particles}

The particle size distribution curve of the representative soil sample obtained through the sieve analysis method is shown in Figure 1. According to the grading curve, the soil samples smaller than $0.075 \mathrm{~mm}$ accounted for $2.84 \%$ of total sample mass and those smaller than $2 \mathrm{~mm}$ accounted for $88 \%$, the soil uniformity coefficient $\mathrm{C}_{\mathrm{u}}$ was 4.55 , the coefficient of curvature $\mathrm{C}_{\mathrm{c}}$ was 1.33 , so the filler gradation was poor, and the particle sizes were relatively concentrated.

\footnotetext{
*Corresponding author:1289578350@qq.com
} 


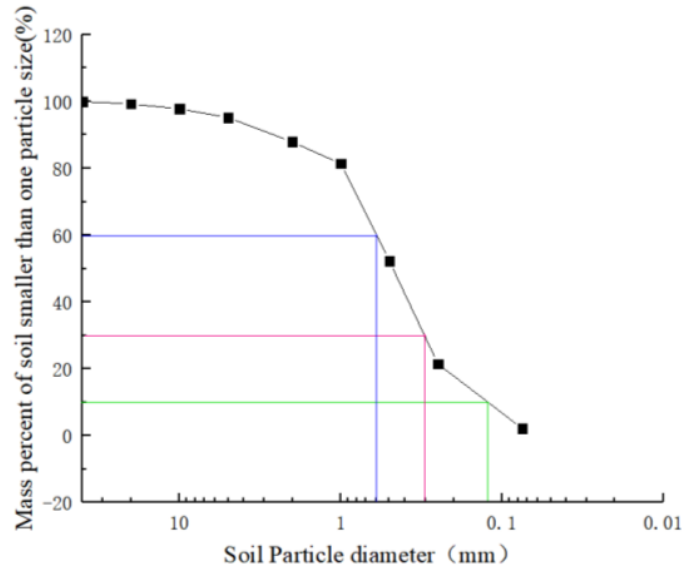

Fig. 1. Curve Chart of Particle Size Distribution.

Table 1: Summary Table of Compaction Test

\begin{tabular}{|c|c|c|}
\hline Name of soil sample & $\begin{array}{l}\text { Maximum dry } \\
\text { density }\left(\mathrm{g} / \mathrm{cm}^{3}\right)\end{array}$ & $\begin{array}{c}\text { Optimal water } \\
\text { content }(\%)\end{array}$ \\
\hline Silty fine sand & 1.96 & 9.7 \\
\hline $\begin{array}{l}\text { Silty fine sand }+2 \% \\
\text { cement }\end{array}$ & 1.97 & 9.3 \\
\hline $\begin{array}{c}\text { Silty fine sand }+3 \% \\
\text { cement }\end{array}$ & 1.99 & 9.1 \\
\hline $\begin{array}{c}\text { Silty fine sand }+4 \% \\
\text { cement }\end{array}$ & 1.97 & 9.1 \\
\hline $\begin{array}{c}\text { Silty fine sand }+5 \% \\
\text { cement }\end{array}$ & 2.02 & 9.0 \\
\hline $\begin{array}{c}\text { Silty fine sand }+6 \% \\
\text { cement }\end{array}$ & 2.02 & 9.5 \\
\hline
\end{tabular}

\subsection{Compaction characteristics of silty fine sand}

By reference to Code for Soil Test of Railway Engineering (TB10102-2010) (hereinafter abbreviated "the Code"), the mass percent of soil samples with the particle size of greater than $5 \mathrm{~mm}$ should be $4.8 \%$, so the compaction test was done using the $\mathrm{Z1}$ method after the air-dried soil samples passed the $5 \mathrm{~mm}$ standard sieve. All cement used in the test was $325^{\#}$ slag Portland cement (delayed coagulation), and the compaction results are summarized in Table 1.

Through Table 1, it could be known that:

The maximum dry density of cement-improved silty fine sand was $1.96-2.02 \mathrm{~g} / \mathrm{cm}^{3}$ (cement content was $0-6 \%$, dry mass ratio); the maximum dry density was positively correlated with the cement content, and the optimal water content was $9.0-9.7 \%$.

\section{Mechanical Properties of Soil Samples}

\subsection{Unconfined compressive strength test}

By reference to Code for Design of Railway Earth Structure (TB10001-2016) and according to class of track, the compaction coefficient of filler beneath the bed and that on the bed bottom should be over 0.90 and 0.93, respectively. Therefore, the samples were prepared under the compaction coefficient of 0.90 and 0.93 , the sample size was $50 \mathrm{~mm} \times 50 \mathrm{~mm}$ (diameter $\times$ height), and the calculation was done through Equation (1) in the sample preparation. The samples were molded once for all, and after the molding, they were cured at temperature of $20 \pm 2^{\circ} \mathrm{C}$ and relative humidity of $95 \%$ for $7 \mathrm{~d}, 14 \mathrm{~d}$ and $28 \mathrm{~d}$. On the last day of curing age, the samples were soaked in water for $24 \mathrm{~h}$, and the water was $2.5 \mathrm{~cm}$ higher than the sample top. Next, their $7 \mathrm{~d}, 14 \mathrm{~d}$ and $28 \mathrm{~d}$ saturated unconfined compressive strengths were measured.

$$
m_{s g}=\rho_{d g} V K\left(1+0.01 w_{s g}\right)
$$

Where:

$m_{s g}$ - necessary quantity of soaking mixture $(\mathrm{g})$;

$w_{s g}$ - water content of soaking mixture (\%);

$\rho_{d g}$ - dry density of chemically improved sample $\left(\mathrm{g} / \mathrm{cm}^{3}\right)$;

$V$-volume of test mold $\left(\mathrm{cm}^{3}\right)$;

$K$-compaction coefficient.

Figure 2 is the histogram of unconfined compressive strength of cement-improved silty fine sand fillers under different cement contents. Under fixed compaction coefficient and curing age, the unconfined compressive strength was increased with the increase in the cement content, and the two showed a favorable linear fitting relation (correlation coefficient of linear fitting: $\mathrm{R}^{2}=0.99625$ ). The histogram of unconfined compressive strength of cement-improved silty fine sand filler (cement content of $3 \%$ and compaction degree of 0.90 ) at different curing ages is shown in Figure 3. When the cement content and compaction coefficient were certain, the sample strength at $7 \mathrm{~d}, 14 \mathrm{~d}$ and $28 \mathrm{~d}$ was $0.484 \mathrm{MPa}, 0.653 \mathrm{MPa}$ and $0.744 \mathrm{MPa}$, respectively. It could be seen that the strength was gradually enhanced with the curing age, but the growth amplitude was gradually reduced. Figure 4 displays the histogram of unconfined compressive strength of cement-improved silty fine sand fillers under different degrees of compaction. Under certain cement content $(3 \%)$ and curing age $(7 d)$, the sample strength was $0.484 \mathrm{MPa}$ under the compaction degree of 0.90 and that under 0.93 was $0.529 \mathrm{MPa}$, so the strength changed somehow with the increase in the degree of compaction, but, to a small extent.

\subsection{Delay time of cement-improved silty fine sand}

The field construction of improved soil mainly experiences the mixing-spreading-compaction stages, the delay time of cement-improved soil refers to the time duration from the addition of the cement into the mixture until the completion of compaction, and it will generate a certain influence on the compaction quality and strength $(7 \mathrm{~d}$ saturated unconfined compressive strength) of cement-improved soil, so the time delay of improved soil is of great importance to the control of construction nodes and construction quality. Those corresponding to the field compaction of improved soil are mainly laboratory compaction test and $7 \mathrm{~d}$ saturated unconfined compressive strength test under a certain delay time, where the latter was mainly explored in this 
study under the delay time. In this test, the delay time was the duration since the cement mixing until the sample was prepared in the laboratory. To specify the $7 \mathrm{~d}$ saturated unconfined compressive strength test under the delay time, the full amount of mixture (cement content of 3\% and compaction degree of 0.90 ) was soaked under the maximum dry density and optimal water content obtained through the standard compaction experiment, the samples were immediately prepared, and the next group of specimens would be prepared every other half an hour after this. In the sample preparation, the calculation was carried out through Equation (1). The curing was done according to the Code, the samples were then soaked, and the saturated unconfined compressive strength of cementimproved silty fine sand filler under each delay time was measured. The relation curve between strength retention rate and time delay is seen in Figure 5. The strength retention rate was the ratio of $7 \mathrm{~d}$ saturated unconfined compressive strength of each sample under a delay time to that under the delay time of 0 .

As shown in Figure 5, the $7 d$ saturated unconfined compressive strength of the samples was gradually reduced with the delay time, namely, the strength retention was under the gradual decline. The strength retention rate of cement-improved silty fine sand showed a good linear fitting relation with the delay time (the correlation coefficient of linear fitting: $\mathrm{R}^{2}=0.983$ ). By reference to Code for Design of Railway Earth Structure (TB100012016) and the class of track, the $7 \mathrm{~d}$ saturated unconfined compressive strength of chemically improved soil on the embankment beneath the bed should be not less than $200 \mathrm{KPa}$, the delay time should reach $5 \mathrm{~h}$ or so, and the strength should be reduced to about $50 \%$ of the initial value, but the strength should still meet the code requirements, which can provide sufficient time for the field construction.

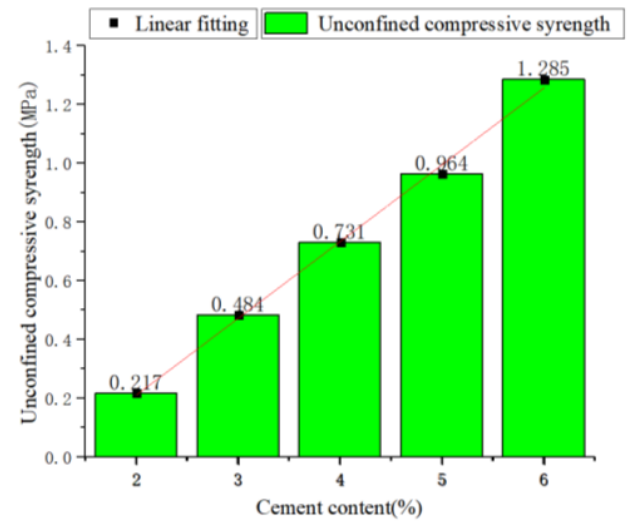

Fig.2.Unconfined Compressive Strength of Unconfined Compressive Strength of Cement-Improved Silty Fine Sand under Different Cement Contents.

\section{Field Compaction Test}

Restricted by the field construction conditions, the compaction test of the test segment in the field

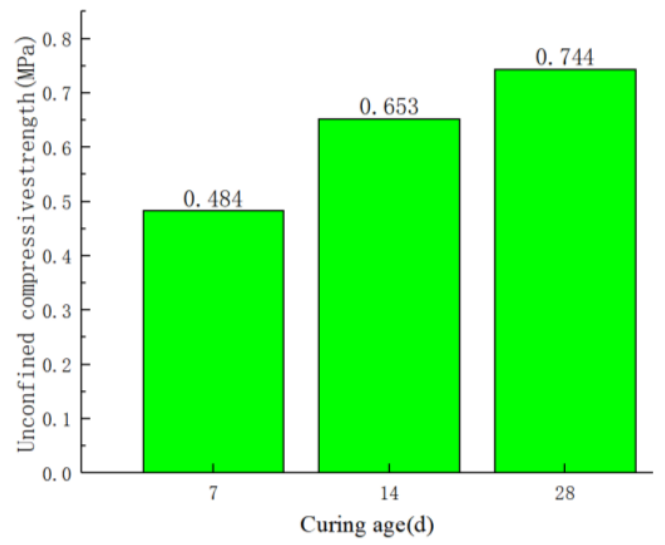

Fig.3.Unconfined Compressive Strength of Cement-Improved Silty Fine Sand at Different Curing Ages.

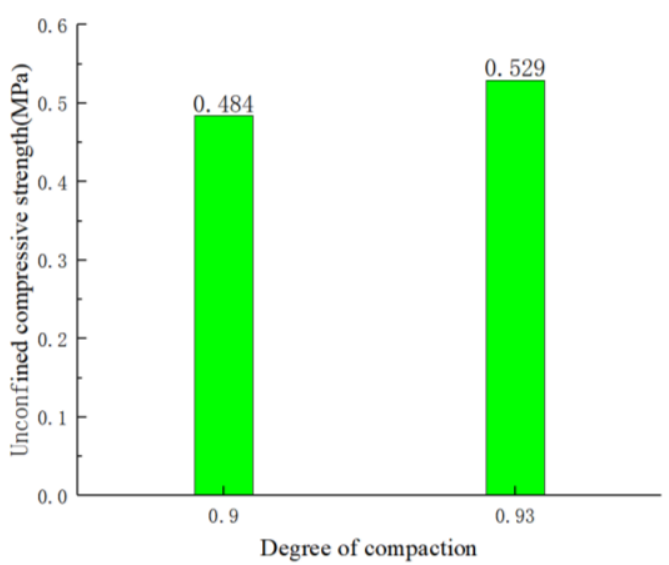

Fig.4.Unconfined Compressive Strength of Cement-Improved Silty Fine Sand under Different Degrees of Compaction.

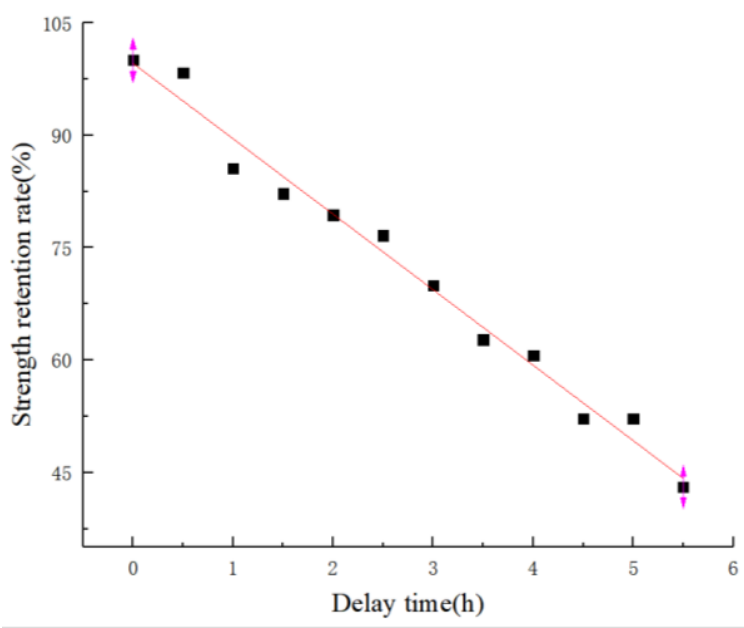

Fig.5.Delay Time-Strength Relation construction was conducted based on the laboratory test. On the one hand, whether the compaction parameters of the fillers at the construction site met the complex standard was verified, and on the other hand, a set of the optimal construction technologies were explored. The construction efficiency was improved and the construction cost was lowered in the large-area construction. The mixin-place was adopted in the test segment, and different loose paving thickness values $(35 \mathrm{~cm}, 37 \mathrm{~cm})$ and different 
compaction times were set, where under five compaction times, the compaction order was static pressure $\rightarrow$ weak vibration $\rightarrow$ strong vibration $\rightarrow$ strong vibration $\rightarrow$ static pressure; when the number of compaction times was seven, the compaction order was static pressure $\rightarrow$ weak vibration $\rightarrow$ strong vibration $\rightarrow$ strong vibration $\rightarrow$ strong vibration $\rightarrow$ strong vibration $\rightarrow$ static pressure. According to the field compaction effects of improved fillers, the detection results could hardly reach the actual difficulty required by the degree of compaction, so the ex post detection method was used on the field, namely, after the compaction of this layer was completed, the compaction degree of filler at the next layer was detected instead of detection from the surface compaction layer according to the sand-cone method, and the laboratory test was verified through the field compaction test, the concrete parameters of which are seen in Table 2.

From Table 2, under a certain loose paving thickness, the number of compaction times should be increased in order to ensure the compaction quality of subgrade. When the number of compaction times was fixed, the greater the loose paving thickness, the lower the compaction quality, because the greater the loose paving thickness, the weaker the transfer of overburden pressure and vibration frequency. For the improved filler on the field, the paving thickness and number of compaction times were recommended as $35 \mathrm{~cm}$ and 7 , respectively.

Table 2: Compaction Effects under Different Compaction Times and Loose Paving Thickness Values

\begin{tabular}{|c|c|c|c|c|}
\hline $\begin{array}{l}\text { Loose paving } \\
\text { thickness }(\mathrm{mm})\end{array}$ & $\begin{array}{c}\text { Number of } \\
\text { compaction times }\end{array}$ & Measuring point & $\begin{array}{l}\text { Compaction } \\
\text { coefficient } K\end{array}$ & $\begin{array}{c}\text { Subgrade coefficient } \\
\mathrm{K}_{30}(\mathrm{MPa} / \mathrm{m})\end{array}$ \\
\hline \multirow{4}{*}{35} & \multirow[t]{2}{*}{5} & 1 & 0.90 & 87 \\
\hline & & 2 & 0.91 & 80 \\
\hline & \multirow[t]{2}{*}{7} & 1 & 0.91 & 85 \\
\hline & & 2 & 0.91 & 92 \\
\hline \multirow{4}{*}{37} & \multirow[t]{2}{*}{5} & 1 & 0.87 & 87 \\
\hline & & 2 & 0.90 & 83 \\
\hline & \multirow[t]{2}{*}{7} & 1 & 0.92 & 89 \\
\hline & & 2 & 0.90 & 94 \\
\hline
\end{tabular}

\section{Reinforcement Mechanism Analysis of Cement-Improved Silty Fine Sand}

After the cement was mixed with silty fine sands, the components in the cement would experience intense hydrolysis and hydration reactions with the moisture in the silty fine sand. The cement formed the cement hydration skeleton in all soil pores to constrain the soil particles ${ }^{[3]}$. The main chemical reactions are as follows:

$2\left(3 \mathrm{CaO} \cdot \mathrm{SiO}_{2}\right)+6 \mathrm{H}_{2} \mathrm{O} \rightarrow 2 \mathrm{CaO}_{2} \cdot \mathrm{SiO}_{2} \cdot 2 \mathrm{H}_{2} \mathrm{O}+$ $2 \mathrm{Ca}(\mathrm{OH})_{2}$

$2\left(2 \mathrm{CaO} \cdot \mathrm{SiO}_{2}\right)+4 \mathrm{H}_{2} \mathrm{O} \rightarrow 3 \mathrm{CaO}_{2} \cdot \mathrm{SiO}_{2} \cdot 2 \mathrm{H}_{2} \mathrm{O}+$ $4 \mathrm{Ca}(\mathrm{OH})_{2}$

$3 \mathrm{CaO} \cdot \mathrm{Al}_{2} \mathrm{O}_{3}+6 \mathrm{H}_{2} \mathrm{O} \rightarrow 3 \mathrm{CaO} \cdot \mathrm{Al}_{2} \mathrm{O}_{3} \cdot 6 \mathrm{H}_{2} \mathrm{O}$

$4 \mathrm{Cao} \cdot \mathrm{Al}_{2} \mathrm{O}_{3} \cdot \mathrm{Fe}_{2} \mathrm{O}_{3}+2 \mathrm{Ca}(\mathrm{OH})_{2}+10 \mathrm{H}_{2} \mathrm{O} \rightarrow$ $3 \mathrm{CaO} \cdot \mathrm{Al}_{2} \mathrm{O}_{3} \cdot 6 \mathrm{H}_{2} \mathrm{O}+3 \mathrm{CaO} \cdot \mathrm{Fe}_{2} \mathrm{O}_{3} \cdot 6 \mathrm{H}_{2} \mathrm{O}$

$3 \mathrm{CaSO}_{4}+3 \mathrm{CaO} \cdot \mathrm{Al}_{2} \mathrm{O}_{3}+32 \mathrm{H}_{2} \mathrm{O} \rightarrow 3 \mathrm{CaO} \cdot \mathrm{Al}_{2} \mathrm{O}_{3}$. $3 \mathrm{C}_{\mathrm{a}} \mathrm{SO}_{4} \cdot 32 \mathrm{H}_{2} \mathrm{O}$

Where:

$3 \mathrm{CaO} \cdot \mathrm{SiO}_{2}$ - main component (accounting for
$40 \%-50 \%)$ in the cement, the main factor deciding the strength.

$2 \mathrm{CaO} \cdot \mathrm{SiO}_{2}$ - components with a high percent $(30 \%-35 \%)$ in the cement, mainly generating the longterm strength.

$3 \mathrm{CaO} \cdot \mathrm{Al}_{2} \mathrm{O}_{3}$ - the component accounting for about $6 \%$ of the cement mass, with the fastest hydration speed, being able to facilitate the early setting of cement

$4 \mathrm{CaO} \cdot \mathrm{Al}_{2} \mathrm{O}_{3} \cdot \mathrm{Fe}_{2} \mathrm{O}_{3}$ - the component accounting for about $10 \%$ of the cement mass, being able to facilitate the early strength.

$\mathrm{CaSO}_{4}$ - the component accounting for about $4 \%$ of the cement mass, which can experience the hydration reaction with $3 \mathrm{CaO} \cdot \mathrm{Al}_{2} \mathrm{O}_{3}$ to generate cement bacillus.

\section{1 lon exchange and particle interaction}

In the colloid formed through the cement hydration, $\mathrm{Ca}^{2+}$ and $(\mathrm{OH})^{-}$in $\mathrm{Ca}(\mathrm{OH})^{2}$ presented exchange adsorption with $\mathrm{Na}^{+}$and $\mathrm{K}^{+}$in the soil mass, so the soil particles formed large soil blocks, and the strong adsorption capacity of $\mathrm{Ca}(\mathrm{OH})^{2}$ promoted the further mutual combination of soil blocks, and a stable chain-like structure of cement soil was formed. 


\subsection{Carbonation}

$$
\mathrm{Ca}(\mathrm{OH})_{2}+\mathrm{CO}_{2} \rightarrow \mathrm{CaCO}_{3}+\mathrm{H}_{2} \mathrm{O}
$$

After the cement hydration, the free $\mathrm{Ca}(\mathrm{OH})_{2}$ generated $\mathrm{CaCO}_{3}$ together with $\mathrm{CO}_{2}$ in the air, and in this process, the soil particle solidification exerted a coarse graining effect, and further enhanced the soil strength.

\subsection{Hard setting reaction}

With the cement hydration, a large quantity of $\mathrm{Ca}^{2+}$ was precipitated out of the improved soil and experienced the chemical reactions with $\mathrm{SiO}_{2}$ and $\mathrm{Al}_{2} \mathrm{O}_{3}$, generating water-insoluble stable crystalline minerals, such as $\mathrm{CaO}-\mathrm{Al}_{2} \mathrm{O}_{3}-\mathrm{H}_{2} \mathrm{O}$ hydration products, $\mathrm{CaO}-\mathrm{SiO}_{2}-$ $\mathrm{H}_{2} \mathrm{O}$ hydration products, etc.

After the improved silty fine sand filler was mixed with the cement, it was mainly adhered to the surface of sand particles. Because the particle size of a single sand was much larger than that of cement particles, the cement wrapped the surface of sand particles. As the cement hydration proceeded, the sand particles were cemented into a whole, and high strength was generated after the hardening.

\section{Conclusions}

(1) The fillers used in the project are silty fine sands, with the uniformity coefficient of 4.55 , coefficient of curvature of 1.33 , and main particle size of $0.075-0.5 \mathrm{~mm}$, the particle sizes are relatively concentrated with the uniform particle composition, and they can be hardly compacted.

(2) The saturated unconfined compressive strength of cement-improved silty fine sand is related to the cement content, curing age and compaction coefficient, and the strength shows a good linear fitting relation with the cement content.
(3) The 7d saturated unconfined compressive strength of cement-improved silty fine sand is correlated with the delay time of sample molding. As the delay time is lengthened, the strength is gradually reduced, and the strength retention rate presents a favorable linear fitting relation with the delay time. At the delay time of $5 \mathrm{~h}$, the strength declined to a half of that at $0 \mathrm{~h}$, but it still meets the strength requirement, which provides favorable conditions for the construction.

(4) Due to the special engineering properties of silty fine sand, the compaction surface is still loose in the roadbed compaction process. The ex post method (sandcone method) can be used, namely, the compaction coefficient may not be detected after the filler compaction at this layer is completed, but instead, it will be detected after the filler compaction at the next layer is ended.

\section{References}

1. W,HL.(2020).Stability analysis of Aeolian Sand Embankment in Gobi Area.HIGHWAY.65(05):6165.

2. Zhang,BW.(2019).Experimental study on subgrade filling of fine sand improved soil in the process of dry wet cycle.Railway Engineering.59 (2) : 5456.

3. Tang,YL.(2012).Experimental study on cement modified silty sand filling foe Dahe Railway Subgrade.Railway Standrad Design.(06):24-27.

4. Zhang ,Y.(2017).Compaction characteristics of aeolian sand and compaction technology for filling Heavy Haul Railway Subgrade.Railway Engineering.57 (3) : 77-80.

5. Yan,DF.(2012).Effect of cement modified fine sandy soil on strength and dry density.Railway Construction Technology.(01):60-62. 